Sains Malaysiana 49(7)(2020): 1543-1552

http://dx.doi.org/10.17576/jsm-2020-4907-07

\title{
Kandungan Kemarmaran Stik Ribeye dan Kesannya terhadap Ciri-Ciri Kualiti Tekstur dan Mikrostruktur Daging
}

(Marbling Content of Ribeye Steak and Its Effect on the Textural and Micro-Structural Quality Characteristics of Beef)

Nurul Nuraliya Shahrai, Abdul Salam BabJi, Mohamad Yusof Maskat \& Salma Mohamad Yusop*

ABSTRAK

Kajian ini dijalankan bagi mengenal pasti kandungan lemak intraotot (kemarmaran) dan kesannya terhadap ciri-ciri kualiti tekstur dan mikrostruktur daging stik ribeye daripada empat baka lembu berbeza iaitu Wagyu, Angus, Brahman dan Kedah-Kelantan (KK). Darjah kemarmaran diukur dengan menggunakan analisis imej berkomputer dan didapati mempengaruhi kelembutan daging. Keputusan menunjukkan sampel Wagyu yang mempunyai lemak intraotot yang tinggi (33.90\%), turut mempunyai kapasiti pengekalan lemak (86.32\%) yang tinggi secara signifikan (p<0.05) dan daging yang paling lembut $(p<0.05)$ berbanding sampel Angus, Brahman dan KK. Berdasarkan ciri-ciri mikrostruktur daging, ruangan antara gentian otot dan diameter gentian otot didapati lebih besar bagi Wagyu berbanding sampel lain masing-masing pada ukuran 23.40 dan 47.01 $\mu \mathrm{m}$. Perbezaan kandungan lemak intraotot sampel Wagyu dan KK turut diperlihatkan dalam imej mikrograf sampel daging.

Kata kunci: Analisis profil tekstur; gentian otot; kandungan kemarmaran; lemak intraotot

ABSTRACT

This study was carried out to evaluate the intramuscular fat content (marbling) and its effect on the textural and microstructural quality characteristics of four different beef of Wagyu, Angus, Brahman, and Kedah-Kelantan (KK). Marbling fleck characteristics of ribeye steaks was measured by computerized image analysis and was found to influence meat tenderness. Results showed that Wagyu samples, which had the highest IMF content (33.90\%), also obtained the highest fat retention $(86.32 \%, p<0.05)$ and significantly tender $(p<0.05)$ meat than that of Angus, Brahman, and KK. The space between muscle fiber and the muscle fibre diameter was also higher in Wagyu, at 23.40 and $47.01 \mu \mathrm{m}$, respectively. The differences in intramuscular fat content of Wagyu, and KK were also evident on the micrograph images of the meat samples.

Keywords: Intramuscular fat; marbling content; muscle fibre; texture profile analysis

\section{INTRODUCTION}

Secara teori, kemarmaran berperanan amat penting dalam penilaian rasa daging. Lemak intraotot (IMF) yang mewakili kemarmaran ini memberi kesan positif terhadap penilaian sensori daging bagi setiap atribut rasa terutamanya kelembutan, kejusian dan impak rasa keseluruhan (Frank et al. 2016; Thompson 2004). Kandungan IMF juga memberi kesan kepada peratusan protein dalam sekeping stik atau lebih dikenali sebagai peratusan daging tanpa lemak.

Secara amnya, daging lembu mempunyai 26 hingga $31 \%$ protein yang membentuk struktur seketul daging (Ismail et al. 2019) yang dikenali sebagai komponen miofibrilar. Dalam sekeping daging, protein terdiri daripada tiga komponen utama iaitu miofibrilar, tisu penghubung dan protein sarkoplasmik. Namun begitu, antara ketiga-tiga protein tersebut, komponen miofibrilar dan tisu penghubung merupakan unsur penting dalam menentuukur kekerasan, keliatan dan keanjalan struktur daging(Baldwin etal. 2012; Ismail etal. 2019; Koohmaraie et al. 2002). Komponen miofibrilar dan tisu penghubung dinyahaslikan melalui proses tindak balas kimia dan juga fizikal (Ismail et al. 2019). Kedua-dua komponen protein ini akan mengalami perubahan ketika aktiviti memasak dijalankan akibat daripada proses pemanasan yang memberi kesan kepada ciri-ciri daging selepas dimasak. Menurut Tornberg (2005), proses pengecutan daging akan merembes keluar cecair daripada struktur daging dan menyebabkan berlaku pengelatinan kolagen yang seterusnya memberi kelembutan pada struktur daging. Duan et al. (2015) melaporkan kesan baka Bos taurus dan Bos indikus terhadap kekerasan struktur daging berkait rapat dengan tindak balas enzim calpain dan calpastatin terhadap proses regangan gentian otot.

Kajian ini dijalankan bagi mengenal pasti kesan kandungan lemak intraotot (IMF) ataupun kemarmaran sampel ribeye daripada empat baka berbeza iaitu Wagyu, Angus, Brahman dan Kedah-Kelantan (KK) dan kesannya terhadap kualiti tekstur daging. Selain itu, 
kesan tahap IMF terhadap komponen memasak seperti hasil masakan (CY\%), kapasiti pengekalan lemak (FR\%) dan juga kapasiti pengekalan air (WR\%) turut dikenal pasti. Pencirian mikrostruktur sampel stik ribeye antara stik ribeye yang memiliki kandungan IMF yang paling tinggi dan juga stik yang memiliki kandungan IMF yang paling rendah turut dijalankan menggunakan Mikroskop Imbasan Elektron (SEM).

\section{BAHAN DAN KAEDAH}

\section{PENYEDIAAN SAMPEL STIK RIBEYE}

Blok-blok daging beku diperoleh dari Gourmet Artisan Enterprise, Bukit Jelutong, Selangor, Malaysia dan dipotong mengikut saiz yang dicadangkan oleh AMSA (2015) iaitu berketebalan $1.5 \mathrm{~cm}$. Sampel stik Ribeye disimpan beku di dalam peti sejuk beku (Hitachi R-V910PUK1KSLS - Fridge Freezer, Hitachi, Ltd; Japan) bersuhu $-20^{\circ} \mathrm{C}$ dan kemudian dinyahbeku sebelum kajian seterusnya dijalankan. Setelah stik ribeye dinyahbekukan pada suhu $5{ }^{\circ} \mathrm{C}$ selama 24 jam atau semalaman sebelum dimasak. Visual kemarmaran (IMF \%) diukur pada gambar yang diambil di bawah kawalan prototaip pembiasan cahaya dan diukur menggunakan imbasan perisian imej-J.

\section{PENENTUAN TAHAP KEMARMARAN}

Penentuan tahap kemarmaran pada sekeping stik ribeye diambil dengan menggunakan kamera telefon pintar dengan sampel stik ribeye diletakkan di dalam prototaip pencahayaan bagi mengurangkan pembiasan bayangbayang sampel atau sekeliling. Prototaip ini diadaptasi daripada Basset et al. (2000) dan diolah sedikit seperti Rajah 1. Kemudian gambar dimuat naik dalam perisian Imej-J bagi menentuukur peratus kemarmaran (IMF\%) dengan menggunakan peratusan kontur hitam dan putih.

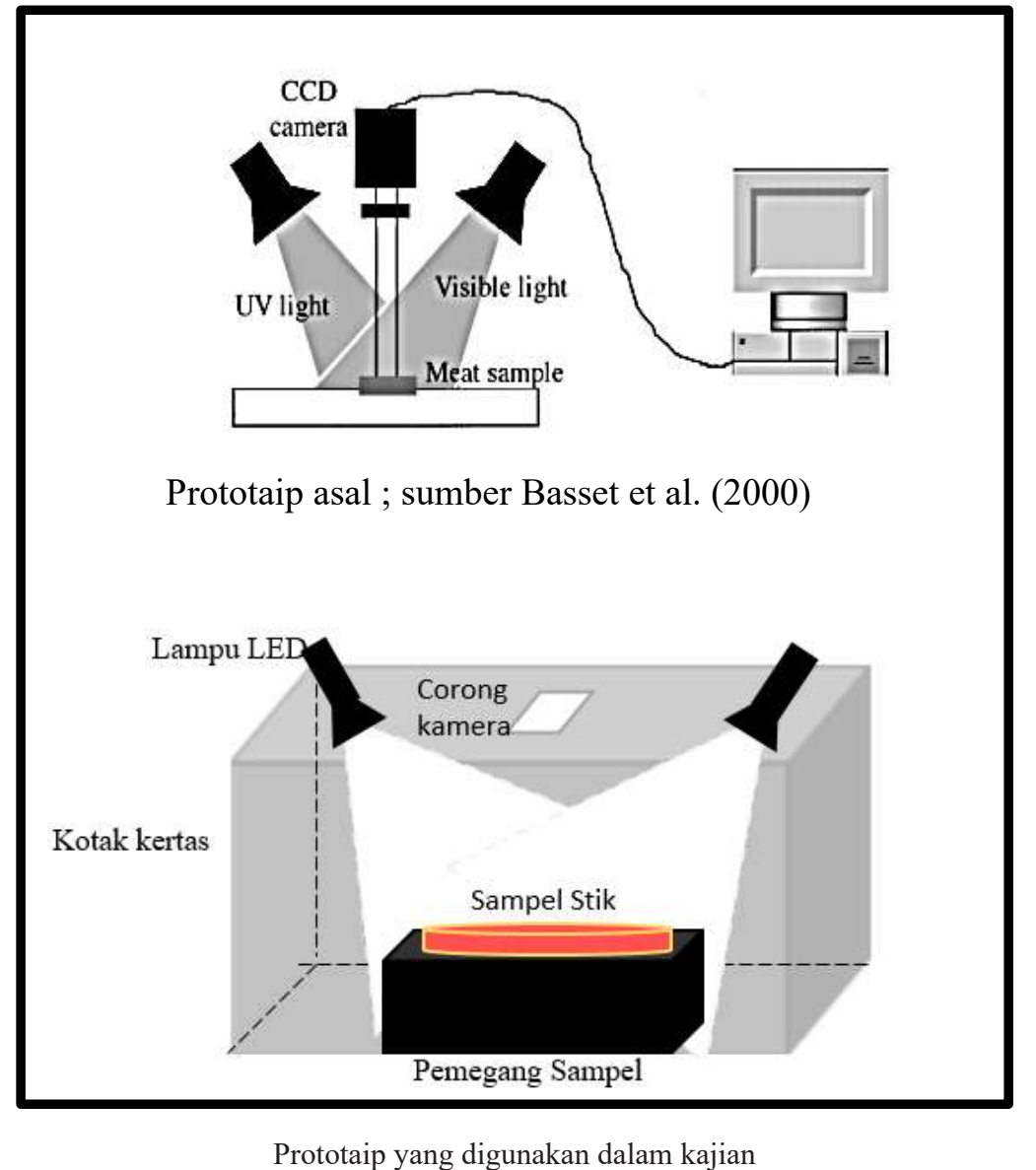

RAJAH 1. Rupa bentuk prototaip pencahayaan 
PENENTUAN PERATUS KELEMBAPAN DAN LEMAK KASAR SAMPEL STIK RIBEYE MENTAH DAN SAMPEL STIK RIBEYE YANG TELAH DIMASAK

Komposisi kelembapan sampel basah (m/o\%) dan lemak kasar (CF\%) dikenal pasti dengan menggunakan prosedur analisis proksimat (AOAC 2012). Komposisi kelembapan diukur dengan menggunakan ketuhar pada suhu $\pm 105{ }^{\circ} \mathrm{C}$ semalaman bagi memastikan berat kering sampel adalah konsisten. Berat sampel yang hilang bersamaan dengan kandungan kelembapan di dalam bahan makanan tersebut. Formula bagi mengenal pasti kelembapan (m/o\%) adalah:

$$
\text { Kelembapan (\%) }=\left(\frac{\text { Sampel setelah dikeringkan }}{\text { Sampel sebelum dikeringkan }}\right) \times 100
$$

Kandungan lemak kasar (CF\%) pula dianalisis dengan menggunakan kaedah Soxhlet seperti yang diterangkan oleh AOAC (2012). Sebanyak 1.0 g sampel ditimbang dan dibalut dengan menggunakan kertas turas. Seterusnya sampel dimasukkan ke dalam jidal pengekstrakan dan disumbat dengan kapas. Jidal pengekstrakan dimasukkan ke dalam kelalang pengekstrakan dan kemudian disambungkan kepada alat Soxhlet. Cawan pengekstrakan yang telah kering ditimbang dan beratnya dicatat. Cawan pengekstrakan diisi dengan $50.0 \mathrm{~mL}$ heksana dan dipasangkan ke alat sistem Soxtec separa auto (Model 1043 Extraction Unit, Sweden). Cawan pengekstrakan yang mengandungi hasil lemak dikeluarkan daripada alat Soxhlet dan dikeringkan dalam ketuhar pada suhu $103{ }^{\circ} \mathrm{C}$ selama 30 min dan disejukkan di dalam balang pengering pada suhu bilik sebelum ditimbang.

$$
\begin{aligned}
& \text { (Berat cawan Pengekstrakan + lemak) - } \\
& \text { Kandungan lemak }(\%)=\frac{\text { Berat cawan Pengekstrakan }}{\text { Berat sampel }} \times 100
\end{aligned}
$$

\section{PENYEDIAAN SAMPEL STIK RIBEYE MENTAH}

Sampel stik yang telah dinyahbeku selama 24 jam pada suhu $5{ }^{\circ} \mathrm{C}$ dimasak dengan menggunakan kaedah memanggang di atas pan pemanas berjarak $8 \mathrm{~cm}$ di atas tuku api. Suhu pan pemanas diselaraskan dan penentuan tahap kemasakan stik seperti yang dicadangkan oleh AMSA (2015) adalah antara 190-232 ${ }^{\circ} \mathrm{C}$ dan 68-71 ${ }^{\circ} \mathrm{C}$. Pemantauan suhu adalah dengan menggunakan termometer inframerah (GS320, China OEM, China) dan juga suhu dalaman stik diukur menggunakan termogandingan (Extreme Deal-32311, China OEM, China).

\section{PENENTUAN PERATUS HASIL MASAKAN, KAPASITI PENGEKALAN LEMAK DAN AIR STIK RIBEYE}

Penentuan komponen masakan seperti penentuan peratus hasil masakan, kapasiti pengekalan lemak dan juga kapasiti pengekalan air ditentukan dengan menggunakan formula oleh Santana et al. (2013). Penentuan peratus hasil masakan pula diadaptasi daripada Maskat dan Kerr (2004) dengan menghitung peratusan berat stik ribeye yang telah dimasak daripada dengan berat stik sebelum dimasak. Kapasiti pengekalan lemak pula merupakan peratusan lemak yang masih berbaki dalam kandungan sampel stik ribeye selepas stik dimasak. Kapasiti pengekalan air pula mewakili kandungan kelembapan yang masih ada kandungan sampel stik ribeye yang selepas dimasak dan ketiga-tiga komponen masakan ini ditentukan dengan formula seperti berikut:

Hasil masakan; $\quad\left(\frac{\text { Berat stik yang telah dimasak }(\mathrm{g})}{\text { Berat stik mentah }(\mathrm{g})}\right) \times 100$
$=\mathrm{CY}(\%)$

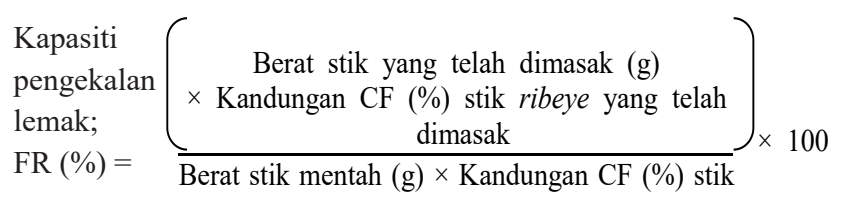

$\begin{aligned} & \text { Kapasiti } \\ & \text { pengekalan } \\ & \text { air; WR }(\%)\end{aligned}=\left(\begin{array}{c}\text { Tahap penghasilan masakan; CY (\%) } \\ \times \begin{array}{c}\text { Kandungan kelembapan (\%) stik ribeye yang } \\ \text { Telah dimasak }\end{array}\end{array}\right)$
100

ANALISIS DAYA RICIH WARNER BRATZLER (WBSF) TERHADAP SAMPEL STIK RIBEYE MENTAH DAN SAMPEL STIK RIBEYE YANG TELAH DIMASAK

Analisis kekerasan tekstur sampel stik ribeye mentah dan yang telah dimasak dilakukan dengan menggunakan mesin Warner Bratzler; TA-XT2 ® (Texture Technologies Crop/Stable Micro System, UK). Sebelum analisis tekstur dijalankan, sampel stik ribeye dipotong kepada bentuk kiub kecil berketebalan $2.5 \mathrm{~cm}$. Bilah akan mericih daging daripada setiap sisi iaitu sama ada mengikut ira atau bertentangan dengan ira gentian otot dan bacaan kekerasan direkod secara purata dan dianalisis.

\section{ANALISIS MIKROSTRUKTUR SAMPEL STIK RIBEYE}

Penyediaan sampel stik untuk imbasan mikrostruktur diadaptasi dan diolah sedikit daripada Pieniazek dan Messina (2016). Keempat-empat sampel stik yang telah dimasak dan sampel mentah dimasukkan ke dalam mesin beku kering pada suhu $40{ }^{\circ} \mathrm{C}$ selama 48 jam di bawah tekanan $0.346 \mathrm{~Pa}$ bagi menghilangkan kelembapan daging. Sampel diletak di atas pemegang sampel SEM dan disaluti dengan emas (Messina et al. 2014). Kemudian, struktur mikroskopik diimbas dengan menggunakan SEM (515, Philips, Amesterdam, Netherland) seperti yang 
dicadangkan dalam kajian terdahulu (Sultana et al. 2008) dengan sedikit pengubahsuaian magnifikasi. Magnifikasi pembesaran yang digunakan dalam kajian ini adalah 50, 250 dan 500×. Kemudian, diameter mikrostruktur gentian otot stik diukur menggunakan imbasan perisian imej-J seperti yang disarankan oleh Baharin et al. (2018).

\section{PENGUMPULAN DAN PENAFSIRAN DATA}

Perisian SPSS (IBM SPSS Statistic 20 (SPSS Inc., Chicago, IL, USA, 2005) digunakan dalam menganalisis data seperti peratus kemarmaran dan tahap komponen masakan (peratus hasil masakan, kapasiti pengekalan lemak dan kapasiti pengekalan air). Dengan menggunakan ANOVADuncan, data dilaporkan dalam bentuk min \pm SE. Manakala ukuran mikrostruktur gentian otot dikenal pasti dengan menggunakan analisis ujian-T dengan perbezaan signifikan iaitu $(\mathrm{p}<0.05)$.

\section{HASIL DAN PERBINCANGAN}

\section{TAHAP KEKERASAN DAN KOMPONEN MEMASAK STIK} RIBEYE DARIPADA EMPAT BAKA LEMBU BERBEZA

Jadual 1 menunjukkan tahap kekerasan tekstur sampel stik ribeye, peratus hasil masakan (CY), kapasiti pengekalan lemak (FR) dan air selepas dimasak (WR). Kajian mendapati Wagyu memiliki kandungan IMF paling tinggi dengan nilai peratusan sebanyak $33.90 \%$. Hal ini turut memberi kesan terhadap kualiti tekstur Wagyu dengan nilai kekerasan paling rendah secara signifikan $(p<0.05)$, iaitu sampel daging paling lembut berbanding baka yang lain dalam kedua-dua keadaan iaitu dalam mentah dan yang telah dimasak, masing-masing dengan nilai 5.61 dan $14.72 \mathrm{~N} / \mathrm{m}^{2}$. Walau bagaimanapun, tahap kekerasan tekstur Angus, Brahman dan KK didapati sebanding ( $>00.05$ ) walaupun kandungan IMF adalah berbeza secara signifikan $(\mathrm{p}<0.05)$.

JADUAL 1. Kandungan lemak intraotot (IMF), kekerasan dan komponen memasak stik Ribeye daripada empat baka lembu berbeza (Min $\pm \mathrm{SE}$ )

\begin{tabular}{|c|c|c|c|c|c|}
\hline \multicolumn{2}{|c|}{ Baka } & Wagyu & Angus & Brahman & KK \\
\hline \multicolumn{2}{|c|}{ Kandungan lemak intraotot; IMF (\%) } & $33.90 \pm 1.00^{\mathrm{a}}$ & $20.87 \pm 1.60^{\mathrm{b}}$ & $12.17 \pm 1.63^{\mathrm{c}}$ & $6.86 \pm 0.67^{\mathrm{d}}$ \\
\hline \multirow[t]{2}{*}{$\begin{array}{l}\text { Kekerasan (N/ } \\
\left.\mathrm{mm}^{2}\right)\end{array}$} & $\begin{array}{l}\text { Sampel stik } \\
\text { mentah }\end{array}$ & $5.61 \pm 0.33^{\mathrm{a}}$ & $11.45 \pm 0.15^{\mathrm{b}}$ & $16.33 \pm 0.41^{\mathrm{c}}$ & $15.51 \pm 0.05^{c}$ \\
\hline & $\begin{array}{l}\text { Sampel stik } \\
\text { yang telah } \\
\text { dimasak }\end{array}$ & $14.72 \pm 0.81^{\mathrm{b}}$ & $33.30 \pm 1.14^{\mathrm{a}}$ & $43.00 \pm 3.90^{\mathrm{a}}$ & $36.59 \pm 7.29^{\mathrm{a}}$ \\
\hline \multicolumn{2}{|c|}{ Hasil masakan (\%) } & $78.77 \pm 2.50^{\mathrm{a}}$ & $72.24 \pm 2.26^{\mathrm{a}}$ & $65.68 \pm 1.90^{\mathrm{b}}$ & $68.97 \pm 1.59^{b}$ \\
\hline \multicolumn{2}{|c|}{ Kapasiti pengekalan lemak (\%) } & $86.32 \pm 2.52^{\mathrm{a}}$ & $55.56 \pm 3.17^{\mathrm{d}}$ & $73.84 \pm 3.60^{\mathrm{b}}$ & $77.63 \pm 2.93^{b}$ \\
\hline \multicolumn{2}{|c|}{ Kapasiti pengekalan air (\%) } & $27.81 \pm 3.62^{b}$ & $37.57 \pm 3.19^{\mathrm{a}}$ & $31.47 \pm 3.25^{\mathrm{ab}}$ & $38.59 \pm 2.90^{\mathrm{a}}$ \\
\hline
\end{tabular}

a,b,ced abjad yang berbeza pada baris yang sama menunjukkan ada perbezaan secara bererti $(\mathrm{p}<0.05)$

Berdasarkan penemuan ini, kehadiran kandungan IMF dalam stik didapati mempengaruhi tahap kelembutan daging seperti yang dibuktikan pada sampel Wagyu dan
KK. Keputusan kajian ini disokong oleh penyelidik lain seperti Gotoh et al. (2014) dan Lee et al. (2019) iaitu kelembutan daging dipengaruhi oleh kandungan IMF 
yang tinggi. Ini terbukti apabila gentian otot mudah terputus ketika dikenakan daya fizikal berkemungkinan IMF yang terkandung dalam sampel stik ribeye berfungsi melonggarkan ikatan persilangan gentian-gentian otot dan secara tidak langsung melemahkan integriti struktur daging. Begitu juga dengan struktur protein penghubung seperti kolagen. Secara teori, komponen kolagen lebih banyak terkandung dalam daging yang kurang mengandungi IMF seperti yang dinyatakan bagi sampel stik ribeye KK. Penukaran kolagen kepada gelatin akan memberi kesan positif terhadap aspek kelembutan daging, seterusnya memperbaiki kualiti pemakanan seperti kejusian, kelembutan, rasa yang enak dan skor keseluruhan penerimaan (Dias et al. 2016; Frank et al. 2016; Jung et al. 2016, 2013). Walau bagaimanapun, faktor luaran seperti kaedah penyediaan masakan dan budaya juga berkemungkinan mempengaruhi skor penerimaan sensori daging (Yusop et al. 2012, 2010, 2009a, 2009b).

Aspek baka juga merupakan faktor utama kepada perbezaan kekerasan daging (Park et al. 2018). Kajian terdahulu mendapati baka lembu Bos taurus mempunyai daging yang lebih lembut berbanding Bos indikus kerana persekitaran peliharaan yang berbeza dan memberi kesan terhadap tumbesaran otot (Wheeler et al. 1994). Kajian ini juga turut disokong dengan penemuan kajian oleh Geesink et al. (2006) dan de Souza Rodrigues et al. (2017) iaitu profil protein dalam daging Bos indikus mengandungi komponen calpastatin yang tinggi, bersaing dengan enzim calpain dan menghalang pemutusan ikatan-ikatan protein. Ini menjadikan daging Bos indikus lebih liat dan keras berbanding Bos taurus.

Selain itu, beberapa kajian juga membuktikan lembu daripada baka Bos indikus mengandungi protein kejutan-haba (HSP) yang lebih tinggi berbanding Bos taurus (Mullins et al. 2016; Picard et al. 2012). Namun, kesan HSP ini boleh dikurangkan melalui kaedah genetik dengan menurunkan peratusan genotip Bos indikus, yang menyebabkan potensi HSP akan menurun dan lembu tersebut menghasilkan daging yang lembut (Carvalho et al. 2014; Highfill et al. 2012; Mullins et al. 2016; O’Connor et al. 1997).

Jadual 1 juga menunjukkan sampel stik ribeye yang mempunyai kandungan IMF yang tinggi seperti Wagyu, turut mencatatkan kapasiti pengekalan lemak (FR) yang lebih tinggi secara signifikan $(\mathrm{p}<0.05)$ dan kapasiti pengekalan air (WR) yang lebih rendah berbanding sampel lain iaitu 86.32 dan $27.81 \%$. Sampel stik ribeye Brahman dan KK pula merekodkan keputusan yang sebanding $(\mathrm{p}>0.05)$ manakala Angus mencatatkan kapasiti pengekalan lemak yang paling rendah secara signifikan $(\mathrm{p}<0.05)$ dengan nilai $55.56 \%$. Ketiga- tiga komponen memasak ini jelas dipengaruhi oleh kandungan IMF sampel stik ribeye. Menurut Santana et al. (2013), kaedah memasak mengalirkan haba kepada daging boleh mengakibatkan tekstur menjadi kering dan kurang berjus, seterusnya memberi kesan terhadap peratus hasil masakan (CY).

Daripada keputusan ini, dua faktor yang berkemungkinan mempengaruhi kandungan air yang terbebas keluar adalah; pertama, kadar penyahaslian protein yang memerangkap molekul air dalam gentiangentian protein (Frank et al. 2015). Semakin tinggi kandungan IMF dalam daging, semakin kurang air yang dapat dirembeskan ketika proses memasak dijalankan. Hal ini berkemungkinan kerana kekurangan gentian otot dan tisu penghubung setiap unit isi padu daging berpotensi mengandungi kandungan kelembapan yang rendah justeru kurang membebaskan air ketika dimasak. Kedua, IMF sebagai penebat haba (Calkin \& Sullivan 2007) dengan daging yang memiliki kandungan IMF yang tinggi berkebolehan menghalang penyahaslian protein yang terikat di antaranya. Oleh kerana pengaliran haba yang lebih lama berbanding stik yang kurang kandungan IMF, stik yang mengandungi kandungan IMF terbentuk dengan elok walaupun dikenakan haba yang tinggi.

\section{IMBASAN MIKROSTRUKTUR STIK RIBEYE WAGYU DAN KEDAH-KELANTAN (KK)}

Imbasan mikrostruktur stik dikenal pasti terhadap stik yang mempunyai tekstur yang paling lembut (Wagyu) dan paling keras (KK). Mikrostruktur stik mentah dan stik yang telah dimasak diambil bagi memperhalusi perbezaan yang terdapat dalam kedua-dua stik. Dengan menggunakan magnifikasi 50, 200 dan 500×, keputusan direkodkan seperti dalam Rajah 2.

Berdasarkan Rajah 2, terdapat perbezaan yang ketara dilihat pada struktur stik iaitu ruangan di antara gentian otot dan tiub endomisium. Sampel Wagyu menunjukkan ruangan yang lebih kecil berbanding sampel KK. Gentian otot sampel Wagyu dilihat lebih kukuh dan lebar berbanding gentian otot sampel KK. Terdapat juga lapisan lemak dalam sampel Wagyu yang menyaluti gentian-gentian otot yang menurut Calkins dan Sullivan (2007), komponen lemak ini mempunyai daya penebat haba. Hal ini berkemungkinan dikaitkan dengan parameter-parameter yang dihitung iaitu kapasiti pengekalan lemak dan juga air di dalam stik selepas dimasak serta kekerasan stik sebelum dan selepas dimasak. Secara tidak langsung, menghasilkan kualiti daging yang memberi skor tertinggi dalam aspek kejusian seperti yang ditunjukkan dan pernah dilaporkan oleh Frank et al. (2016). 


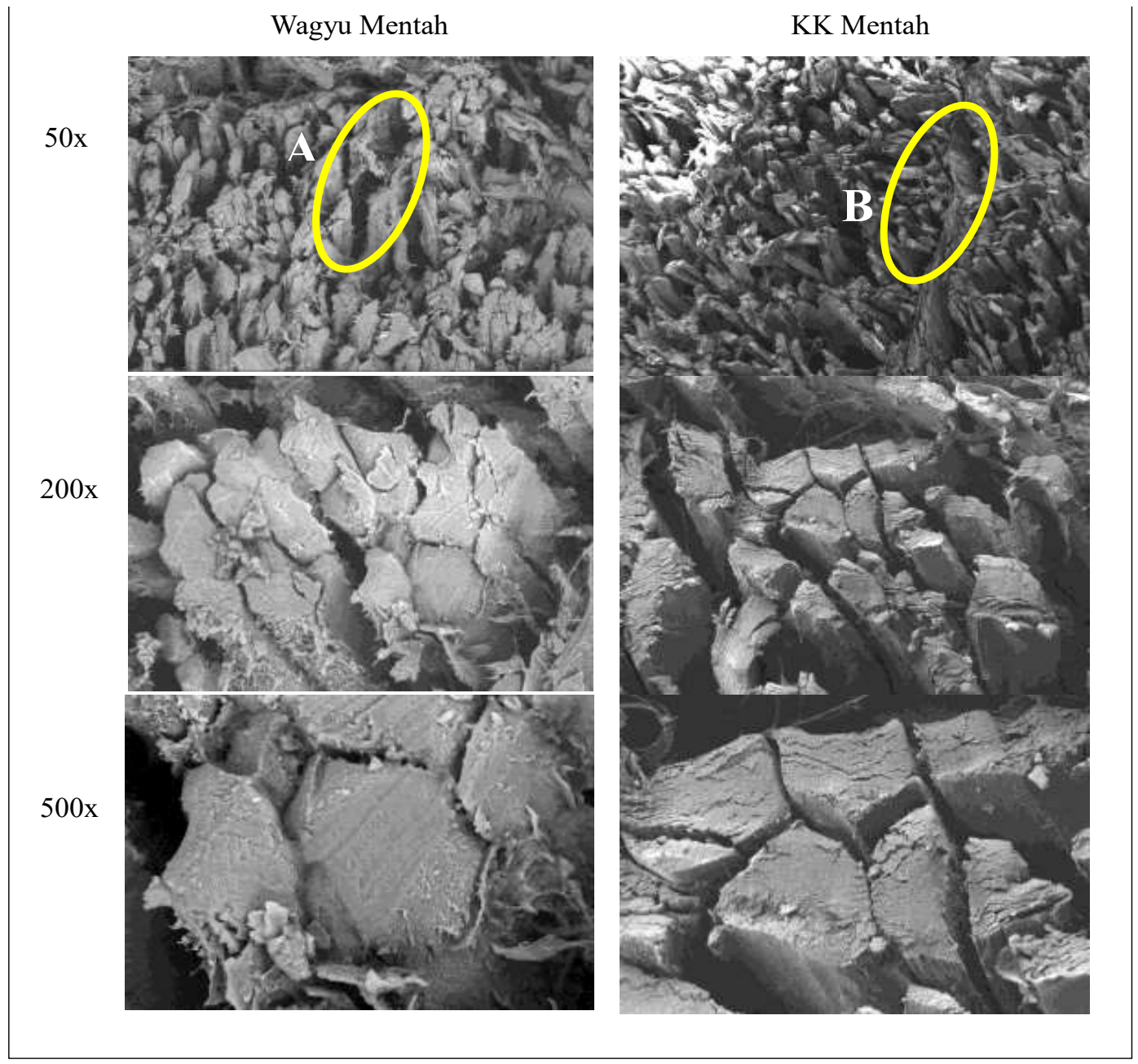

A- jalur endomisium sampel stik ribeye Wagyu

B- jalur endomisium sampel stik ribeye KK

RAJAH 2. Imbasan mikrostruktur keratan rentas mengikut magnifikasi

$(50,200,500 x)$ bagi stik ribeye mentah mengikut baka berbeza

JADUAL 2. Ukuran gentian otot bagi stik mentah antara Wagyu dan KK $(\mathrm{Min} \pm \mathrm{SE})$

\begin{tabular}{lcc}
\hline \multicolumn{1}{c}{ Kumpulan } & Wagyu & KK \\
\hline Ruangan antara gentian otot $(\mu \mathrm{m})$ & $23.40 \pm 1.15^{\mathrm{a}}$ & $22.90 \pm 0.95^{\mathrm{b}}$ \\
Diameter gentian otot $(\mu \mathrm{m})$ & $47.01 \pm 2.49^{\mathrm{a}}$ & $32.62 \pm 3.68^{\mathrm{b}}$ \\
\hline
\end{tabular}

${ }^{a \& b}$ abjad yang berbeza pada baris yang sama menunjukkan ada perbezaan secara bererti $(P<0.05)$

Perbezaan saiz dan gentian otot dapat dinyatakan dengan lebih jelas melalui pengukuran menggunakan perisian imej-J. Jadual 2 menunjukkan ukuran ruangan di antara gentian otot dan juga diameter otot sampel stik mentah Wagyu dan juga KK. Terdapat perbezaan yang signifikan $(\mathrm{p}<0.05)$ bagi ruangan dan diameter gentian otot yang ketara lebih besar bagi sampel Wagyu berbanding KK. Gentian otot bagi KK didapati lebih kecil dan regang. Menurut Sultana et al. (2008), struktur daging diikat dengan gentian-gentian otot seperti aktin 


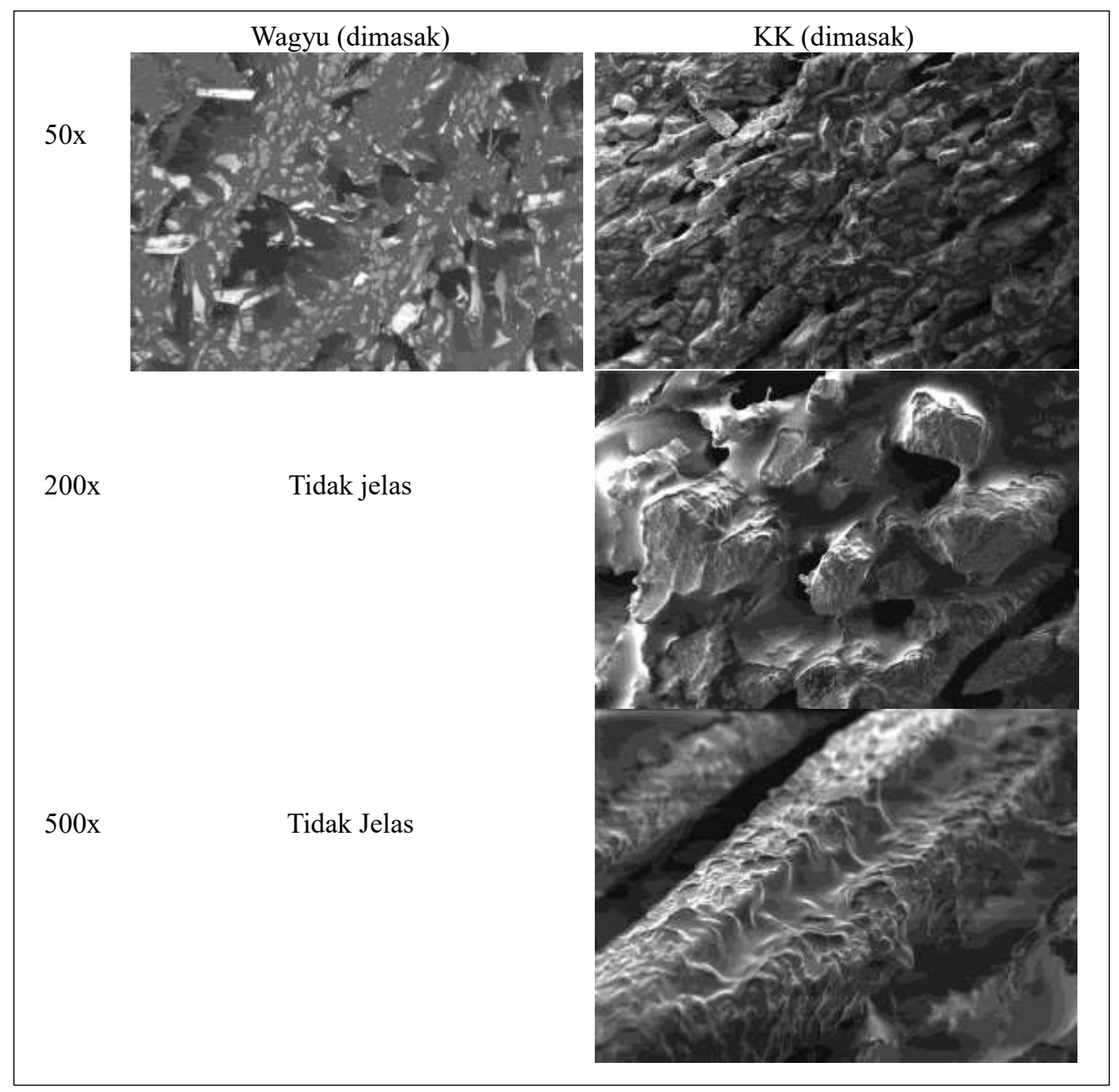

RAJAH 3. Imbasan mikrostruktur keratan rentas mengikut magnifikasi $(50,200,500 x)$ bagi stik ribeye yang telah dimasak mengikut baka berbeza

dan miosin kemudian membentuk aktomiosin. Kegagalan ikatan aktomiosin berkemungkinan menghasilkan struktur daging yang lebih berongga dan kandungan air akan mudah terkumpul sewaktu proses pembekuan.

Berdasarkan Rajah 3, sampel stik ribeye Wagyu jelas menunjukkan gumpalan lemak yang mencair telah melekat dan mengikat gentian-gentian otot. Namun, imbasan bermagnifikasi 200 dan 500× gagal diambil secara terperinci kerana tidak dapat menembusi lapisan lemak yang tersalut di sekeliling gentian otot. Berbeza dengan struktur stik KK, sampel ini jelas menunjukkan organisasi gentian otot yang tidak sekata akibat pemanasan. Pemecahan mikrofiber dan penyahaslian komponen kolagen juga kelihatan pada struktur stik ribeye $\mathrm{KK}$ pada magnifikasi $500 \times$.

Menurut Ishihara et al. (2013), kaedah masakan mempengaruhi kelajuan haba menuju kepada sampel stik. Semakin laju haba dikenakan pada sampel, semakin cepat pemusnahan ikatan-ikatan mikrostruktur otot dan akhirnya memberi kesan kepada kelembutan daging.
Walaupun begitu, ukuran diameter tidak dapat diambil melalui imbasan keratan rentas kerana diselaputi lemak yang mencair menyebabkan imbasan mikrostruktur kurang jelas. Namun begitu, keratan struktur selari stik dapat dikenal pasti seperti dalam Rajah 4 dengan magnifikasi yang sama iaitu 50, 200 dan 500×.

Berdasarkan Rajah 4, KK pada magnifikasi $500 \times$ jelas menunjukkan fenomena pengherotan sepanjang gentian otot dan hal ini membuktikan pembentukan pecahan ini bukan fenomena yang pasif, tetapi memerlukan daya luaran yang agresif seperti penghabaan. Tambahan pula, fenomena pengherotan ini menunjukkan fungsi komponen protein kejutan-haba (HSP) yang terkandung dalam daging lembu Bos indikus seperti lembu KK. Menurut Palka dan Daun (1999), pengecutan awal otot berkait dengan penyahaslian miosin akibat daripada tekanan haba yang tinggi dan membenarkan sebilangan besar kandungan air terbebas keluar. Hal ini berkaitan dengan keadaan pan pemanas yang bersuhu $190-232^{\circ} \mathrm{C}$ (AMSA 2015) sebelum proses 


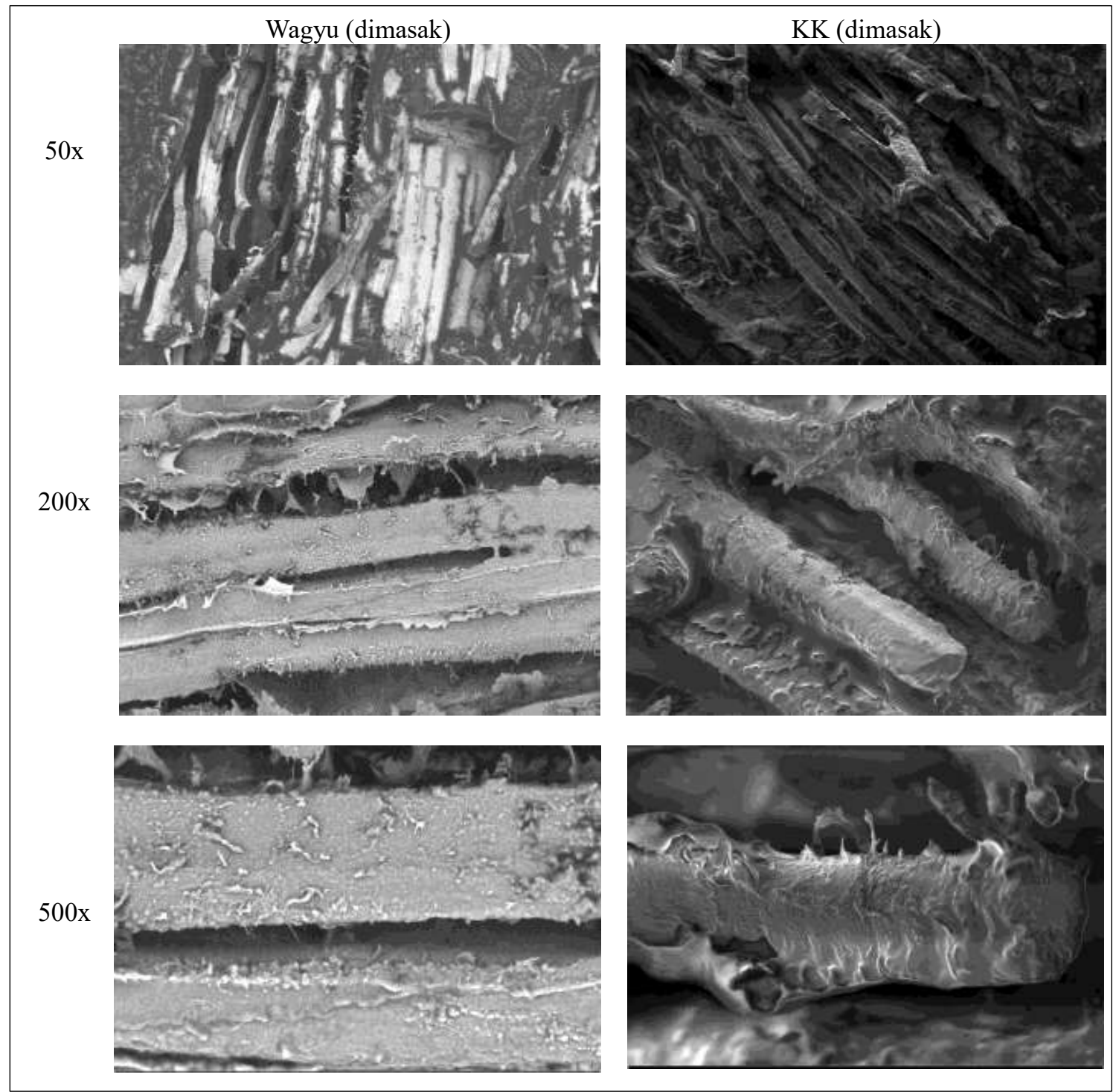

RAJAH 4. Mikrostruktur keratan selari stik yang telah dimasak

memasak bermula. Kemudian, pengecutan ikatan persilangan aktin-miosin, memerangkap kandungan air walaupun proses rembesan air masih berlaku sehingga stik selesai dimasak pada suhu yang dikehendaki.

Selain itu, kajian ini juga membuktikan IMF sebagai pengikat. Secara teori, pengikat digunakan dalam pemprosesan daging bagi meningkatkan pembentukan rangkaian struktur protein, pengikatan air dan juga lemak (Heinz \& Hautzinger 2007). Justeru, berkemungkinan, terdapat fenomena pengekalan lemak dalam stik yang dimasak dan peratusannya berkait dengan kandungan IMF dalam stik ribeye itu sendiri. Kajian ini turut disokong oleh Foster et al. (2011) dan Frank et al. (2015) selain daripada fungsi IMF sebagai penebat seperti yang dicadangkan oleh Calkin dan Sullivan (2007).

\section{KESIMPULAN}

Kesimpulannya, sampel stik ribeye yang memiliki kandungan lemak intraotot (IMF) yang tinggi didapati menghasilkan stik yang lebih lembut sama ada sebelum atau selepas dimasak. Kandungan IMF turutmempengaruhi komponen memasak pada stik termasuk hasil memasak, kapasiti pengekalan lemak dan kapasiti pengekalan air daging. Kesan perbezaan kandungan lemak intraotot bagi sampel berlainan baka turut dapat dilihat dengan jelas pada ciri-ciri mikstrostruktur daging hasil daripada 
imbasan mikroskop elektron. Cadangan kajian lanjutan berkenaan penilaian rasa daging akan membuktikan bahawa perbezaan kandungan lemak intraotot ini bukan sahaja dapat diukur secara instrumental, tetapi juga secara sensori.

\section{PENGHARGAAN}

Kajian ini merupakan sebahagian daripada kerja-kerja penyelidikan di bawah Geran Universiti Penyelidikan (GUP) (GUP-2018-028) dari Universiti Kebangsaan Malaysia. Penulis merakamkan jutaan terima kasih kepada Gourmet Artisan Enterprise atas sumbangan sampel stik lembu yang digunakan dalam kajian ini dan Encik Ahmad Zaki Zaini dari Unit Mikroskopi Elektron, Universiti Kebangsaan Malaysia atas sumbangan teknikal melibatkan penggunaan Mikroskop Imbasan Elektron.

\section{RUJUKAN}

American Meat Science Journal Association (AMSA) 2015. Cookery, Sensory Evaluation and Instrumental Tenderness Measurement of Meat Guidelines. Champaign, IL: Meat Science Association.

AOAC. 2012. Official Methods of Analysis. Washington: Association Official Analysis of Chemistry.

Baharin, K.W., Zakaria, S., Ellis, A.V., Talip, N., Kaco, H., Gan, K., Zailan, F.D. \& Hashim, S.N.A.S. 2018. Factors affecting cellulose dissolution of oil palm empty fruit bunch and kenaf pulp in naoh/urea solvent. Sains Malaysiana 47(2): 377-386.

Basset, O., Buquet, B., Abouelkaram, S., Delachartre, P. \& Culioli, J. 2000. Application of texture image analysis for the classification of bovine meat. Food Chemistry Journal 69(4): 437-445.

Baldwin, D.E. 2012. A review: Sous vide cooking. International Journal of Gastronomy and Food Science 1(1): 15-30.

Calkins, C.R. \& Sullivan, G. 2007. Ranking of Beef Muscle for Tenderness. Beef Facts Product Enhancement. National Cattlemens Beef Association.

Carvalho, M.E., Gasparin, G., Poleti, M.D., Rosa, A.F., Balieiro, J.C.C., Labate, C.A., Nassu, R.T., Tullio, R.R., Regitano, L.C.A., Mourao, G.B. \& Coutinho, L.L. 2014. Heat shock and structural proteins associated with meat tenderness in Nellore beef cattle, a Bos indicus breed. Meat Science Journal 96(3): 1318-1324.

de Souza Rodrigues, R.T., Chizzotti, M.L., Vital, C.E., Baracat-Pereira, M.C., Barros, E., Busato, K.C., Gomes, R.A., Ladeira, M.M. \& Martins, T.D.S. 2017. Differences in beef quality between angus (Bos taurus taurus) and nellore (Bos taurus indicus) cattle through a proteomic and phosphoproteomic approach. PLOS ONE 12(1): e0170294.

Dias, L.S., Hadlich, J.C., Luzia, D.M.M. \& Jorge, N. 2016. Influence of breed on beef and intramuscular fat quality from Nellore (Bos indicus) and Wagyu (Bos taurus) crossbreed cattle. International Food Research Journal 23(4): 15231530 .

Duan, Q., Tait Jr., R.G., Schneider, M.J., Beitz, D.C., Wheeler, T.L., Shackelford, S.D., Cundiff, L.V. \& Reecy, J.M.
2015. Sire breed effect on beef longissimus mineral concentrations and their relationships with carcass and palatability traits. Meat Science Journal 106(1): 25-30.

Foster, K.D., Grigor, J.M.V., Cheong, J.N., Yoo, M.J.Y., Bronlund, J.E. \& Morgenstern, M.P. 2011. The role of oral processing in dynamic sensory perception. Journal of Food Science 76(1): 49-61.

Frank, D., Eyres, G.T., Piyasiri, U., Cochet-Broch, M., Delahunty, C.M., Lundin, L. \& Appelqvist, I.M. 2015. Effects of agar gel strength and fat on oral breakdown, volatile release and sensory perception using in vivo and in vitro systems. Journal of Agriculture and Food Chemistry 63(41): $9093-$ 9102.

Frank, D., Joo, S.T. \& Warner, R. 2016. Consumer acceptability of intramuscular fat. Korean Journal Animal Science 36(6): 699-708.

Geesink, G.H., Kuchay, S., Chishti, A.H. \& Koohmaraie, M. 2006. $\mu$-Calpain is essential for postmortem proteolysis of muscle proteins. Journal of Animal Science 84(10): 28342840.

Gotoh, T., Takahashi, H., Nishimura, T., Kuchida, T. \& Mannen, H. 2014. Meat produced by Japanese Black cattle and Wagyu. Asian-Australasian Journal of Animal Science 31(7): 933-950

Heinz, G. \& Hautzinger, P. 2007. Meat Processing Technology for Small to Medium Scale Producers. RAP Publication 2007/20. FAO, Bangkok.

Highfill, C.M., Esquivel-Font, O., Dikeman, M.E. \& Kropf, D.H. 2012. Tenderness profiles of ten muscles from F1 Bos indicus $\times$ Bos taurus and Bos taurus cattle cooked as steaks and roasts. Meat Science Journal 90(4): 881-886.

Ishihara, Y., Moreira, R., de Souza, G., Salviano, A. \& Madruga, M. 2013. Study of the Warner-bratzler shear force, sensory analysis and sarcomere length as indicators of the tenderness of sun-dried beef. Journal of Molecules 18(8): 9432-9440.

Ismail, I., Hwang, Y.H., Bakhsh, A. \& Joo, S.T. 2019. The alternative approach of low temperature-long time cooking on bovine semitendinosus meat quality. Asian-Australasian Journal of Animal Science 32(2): 282-289.

Jung, E.Y., Hwang, Y.H. \& Joo, S.T. 2016. The relationship between chemical compositions, meat quality, and palatability of the 10 primal cuts from Hanwoo steer. Korean Journal of Animal Science 36(2): 137-143.

Jung, S., Nam, K.C., Lee, K.H., Kim, J.J. \& Jo, C. 2013. Meat quality traits of Longissimus dorsi muscle from carcasses of Hanwoo steers at different yield grades. Korean Journal Food Science Animal Resource 33(3): 305-316.

Koohmaraie, M., Kent, M.P., Shackelford, S.D., Veiseth, E. \& Wheeler, T.L. 2002. Meat tenderness and muscle growth: Is there any relationship? Meat Science Journal 62(3): 345-352.

Lee, B. \& Choi, Y.M. 2019. Correlation of marbling characteristics with meat quality and histochemical characteristics in Longissimus thoracis muscle from hanwoo steers. Food Science and Animal Resource Journal 39(1): 151-161.

Maskat, M.Y. \& Kerr, W.L. 2004. Effect of breading particle size on coating adhesion in breaded, fried chicken breasts. Journal of Food Quality 27(2): 103-113. 
Messina, V., Sancho, A., Grigioni, G., Filipini, S., Pazos, A., Paschetta, F., Chamorro, V. \& Walsoe, de.R.N. 2014. Evaluation of different bovine muscles to be applied in freeze drying for instant meal. Study of physicochemical and senescence parameters. Journal of Animal Science 9(1): 723-772.

Mullins, C.R., Zerby, H.N., Fitzpatrick, L.A. \& Parker, A.J. 2016. Bos indicus cattle possess greater basal concentrations of HSP27, alpha B-crystallin, and HSP70 in skeletal muscle in vivo compared with Bos taurus cattle. Journal of Animal Science 94(1): 424-429.

O'Connor, S.F., Tatum, J.D., Wulf, D.M., Green, R.D. \& Smith, G.C. 1997. Genetic effects on beef tenderness in Bos indicus composite and Bos taurus cattle. Journal of Animal Science 75(7): 1822-1830.

Park, S.J., Beak, S-H., Jung, D.J.S., Kim, S.Y., Jeong, I.H., Piao, M.Y., Kang, H.J., Fassah, D.M., Na, S.W., Yoo, S.P. \& Baik, M. 2018. A Review: Genetic, management, and nutritional factors affecting intramuscular fat deposition in beef cattle. Asian-Australasian Journal of Animal Sciences 31(7): 1043-1061.

Palka, K. \& Daun, H. 1999. Changes in texture, cooking losses, and myofibrillar structure of bovine $M$. semitendinosus during heating. Meat Science Journal 51(3): 237-243.

Picard, B., Gagaoua, M., Al-Jammas, M., De-Koning, L., Valais, A. \& Bonnet, M. 2018. A review: Beef tenderness and intramuscular fat proteomic biomarkers: Muscle type effect. Peer-Reviewed Journal 62(40): 4891-4911.

Pieniazek, F. \& Messina, V. 2016. Texture and colour analysis of freeze-dried potato (cv. spunta) using instrumental and image analysis techniques. International Journal of Food Properties 20(6): 1-12.

Santana, P., Huda, N. \& Yang, T.A. 2013. The addition of hydrocolloids (carboxymethycellulose, alginate and konjac) to improve the physicochemical properties and sensory characteristics of fish sausage formulated with surimi powder. Turkish Journal of Fishery and Aquatic Science 13: 561-569.

Sultana, A., Nakanishi, A., Roy, B.C., Mizunoya, W., Tatsumi, R., Ito, T., Tabata, S., Rashid, H., Katayama, S. \& Ikeuchi, Y. 2008. Quality improvement of frozen and chilled beef biceps femoris with the application of salt-bicarbonate solution. Asian-Australasian Journal of Animal Science 21(6): 903-911.

Thompson, J. 2004. The effect of marbling and on flavour and juiciness scores of cooked beef, after adjusting to constant tenderness. Australian Journal of Experimental Agriculture 48(11): 1405-1414.

Tornberg, H. 2005. Effects of heat on meat protein-implications on structure and quality of meat products. Meat Science Journal 70(3): 493-508.

Wheeler, T.L., Cundiff, L.V. \& Koch, R.M. 1994. Effect of marbling degree on beef palatability in Bos taurus and Bos indicus cattle. Journal of Animal Science 72(2): 3145-3151.

Yusop, S.M., O’Sullivan, M.G., Kerry, J.F. \& Kerry, J.P. 2012. Influence of processing method and holding time on the physical and sensory qualities of cooked marinated chicken breast fillets. LWT - Food Science and Technology 46(1): 363-370.

Yusop, S.M., O’Sullivan, M.G., Kerry, J.F. \& Kerry, J.P. 2010. Effect of marinating time and low $\mathrm{pH}$ on marinade performance and sensory acceptability of poultry meat. Meat Science Journal 85(4): 657-663.

Yusop, S.M., O’Sullivan, M.G., Kerry, J.F. \& Kerry, J.P. 2009a. Sensory evaluation of Indian-style marinated chicken by Malaysian and European naïve assessors. Journal of Sensory Studies 24(2): 269-289.

Yusop, S.M., O’Sullivan, M.G., Kerry, J.F. \& Kerry, J.P. 2009 b. Sensory evaluation of Chinese-style marinated chicken by Chinese and European naïve assessors. Journal of Sensory Studies 24(4): 512-533.

Jabatan Sains Makanan

Fakulti Sains dan Teknologi

Universiti Kebangsaan Malaysia

43600 UKM Bangi, Selangor Darul Ehsan

Malaysia

*Pengarang untuk surat-menyurat; email: salma_my@ukm. edu.my

Diserahkan: 17 Disember 2019

Diterima: 8 April 2020 